\title{
Analisis aliran modal asing ke indonesia dengan Pull and push factors
}

\author{
Basri Bado, Arung Samudera, Muhammad Imam Ma'ruf \\ Universitas Negeri Makassar \\ Email: basri.bado@unm.ac.id
}

(Diterima: 15-Juni-2018; di revisi: 10-September-2018; dipublikasikan: 30-Desember-2018)

\begin{abstract}
ABSTRAK
Tujuan penelitian ini menganalisis tentang aliran modal asing ke Indonesia dengan pull dan push factors. Determinan yang digunakan pada Pull dan Push factors adalah GDP Domestik. GDP Global, Suku bunga domestic, suku bunga internasional dan resiko politik negara. Penelitian menggunakan pendekatan kuantitatif dengan menggunakan data time series dengan rentang waktu 20 tahun pasca krisis moneter di Indonesia (1998-2017). Analisis data menggunakan persamaan regresi linear berganda. Hasil penelitian menemukan bahwa ternyata faktor yang dominan mempengaruhi aliran modal asing adalah pull factors baik jenis portofolio investment dan foreign direct investment. Variabel yang paling dominan mempengaruhi aliran modal asing di Indonesia yaitu variabel risiko politik domestik. Risiko politik domestik erat kaitannya dengan iklim investasi. Disisi lain pengaruh aliran modal asing signifikan dan positif dalam menjelaskan pertumbuhan ekonomi di Indonesia.
\end{abstract}

Keyword: Modal asing, Pull and Push factors, time series, regresi berganda.

\begin{abstract}
The purpose of this study is to analyze the flow of foreign capital into Indonesia with pull and push factors. Determinants used on Pull and Push factors are Domestic GDP. Global GDP, domestic interest rates, international interest rates and the country's political risks. The study uses a quantitative approach using time series data with a span of 20 years after the monetary crisis in Indonesia (1998-2017). Data analysis using multiple linear regression equations. The results of the study found that it turned out that the dominant factors influencing foreign capital flows were pull factors both the type of portfolio investment and foreign direct investment. The most dominant variable affecting the flow of foreign capital in Indonesia is the domestic political risk variable. Domestic political risk is closely related to the investment climate. On the other hand the influence of foreign capital flows is significant and positive in explaining economic growth in Indonesia.
\end{abstract}

Keywords: Foreign capital, Pull and Push factors, time series, multiple regression.

Copyright (C) 2018 Universitas Negeri Makassar. This is an open access article under the CC BY license (http://creativecommons.org/licenses/by/4.0/) 


\section{Jurnal Administrare: Jurnal Pemikiran Ilmiah dan Pendidikan Administrasi Perkantoran Vol. 5, No. 2, Juli - Desember 2018, Hal 77-84}

\section{PENDAHULUAN}

Aliran modal yang besar ke suatu negara dimaksudkan sebagai sumber pembiayaan untuk peningkatan perekonomian (Ahmed \& Zlate, 2014; Davis \& Presno, 2017; Kersten, Harms, Liket, \& Maas, 2017; Zaman, Hassan, Akhter, \& Meraj, 2018). Semua negara secara sadar mengetahui bahwa aliran modal yang pada gilirannya digunakan untuk investasi merupakan mesin penggerak pertumbuhan utama yang secara langsung terkait pada perbaikan kinerja perekonomian (Situmorang, 2011). Meskipun arus masuk modal asing dapat menyediakan modal yang dapat mendukung peningkatan perekonomian juga dapat memiliki dampak negatif pada perekonomian dan sistem keuangan negara penerima jika arus modal masuk tidak dikelola dengan baik (Dossani \& Kenney, 2002; Guzman, Ocampo, \& Stiglitz, 2018; Marcelin \& Mathur, 2016; Montiel \& Reinhart, 1999; Vo, 2018).

Pergerakan aliran modal global kebanyakan mengalir ke Asia khususnya ke negara emerging market economics (EMEs) (IMF, 2016). Pergerakan itu dipicu oleh prospek pertumbuhan yang besar di Asia. Aliran modal di Asia menunjukkan perkembangan yang positif meski di tahun-tahun tertentu mengalami penurunan karena fenomena global.

Aliran modal ke negara di Asia didominasi oleh jenis foreign direct investment, hal ini karena pasar di Asia yang memiliki potensi yang menjanjikan untuk para investor. Sementara portofolio investment di Asia bergerak fluktuatif dan pencapaian terbesar terjadi di tahun 2014, namun pada tahun 2015 mengalami penurunan yang signifikan akibat adanya ekspektasi kenaikan Fed Fund Rate menyebabkan modal dalam bentuk portofolio bergerak keluar di beberapa negara EMEs di Asia. Sementara perkembangan other investment pasca krisis global mengalami defisit sampai pada tahun 2013. Hampir semua negara mengalami defisit kecuali China dan India yang menunjukkan pertumbuhan yang positif dari tahun ke tahun. IMF melaporkan bahwa aliran modal ke kawasan Asia dalam kurun waktu 2009 - 2016 didominasi oleh China yang mencapai 65 persen dari total aliran modal di kawasan Asia dan India yang mencapi 12 persen dari total aliran modal di kawasan Asia (IMF, 2016). Sementara itu untuk aliran yang menuju ke kawasan Asia lainnya, aliran modal terlihat cukup diskriminatif karena hanya menuju ke negara yang memiliki kinerja ekonomi yang sehat dan prospek yang cerah.

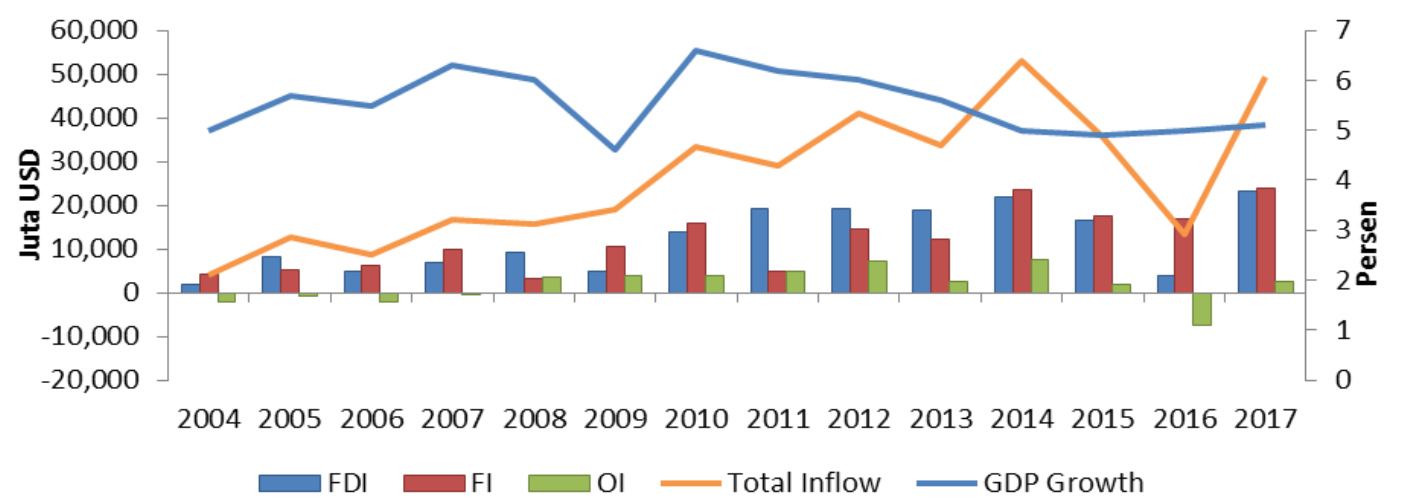

Sumber: Bank Indonesia, 2017

Gambar 1 Aliran Modal Asing di Indonesia 
Basri Bado, Arung Samudera, Muhammad Imam Ma'ruf; Analisis aliran modal asing ..... 79

Aliran modal di Indonesia juga mengalami dinamika, namun memiliki perkembangan yang agak berbeda di tahun-tahun tertentu. Peningkatan aliran modal asing di Indonesia menunjukan peningkatan sejak tahun 2000-an pasca krisis dengan puncaknya terjadi pada tahun 2014. Arus modal yang rendah di awal tahun 2000-an masih tampak masuk akal karena pada saat yang sama arus modal di dunia turun secara signifikan. Sementara itu di tahun 2016 mengalami penurunan yang tajam dan gejala penurunan sudah terlihat di tahun 2015. Penurunan aliran modal asing ini disebabkan karena adanya gejolak perekonomian global yang dipicu oleh dinamika politik Amerika Serikat dan amnesti pajak khususnya repatriasi dana bukan penduduk.

Arus modal ke suatu negara dapat dipengaruhi oleh banyak faktor. Ini termasuk perkembangan ekonomi, sosial dan politik di kedua negara baik negara penerima maupun negara pemberi modal, dan dapat secara luas dibagi menjadi dua kategori utama yaitu push factors (faktor eksternal) dan pull factors (faktor internal). Tinjauan literatur menunjukkan terdapat faktor-faktor domestik sebagai penarik (pull factors) dan faktor-faktor global sebagai pendorong (push factors) aliran modal asing (Koepke, 2015). Dalam kaitan push factor mencakup pertumbuhan ekonomi dunia, suku bunga luar negeri, dan premi risiko di pasar keuangan global, sementara pull factor meliputi pertumbuhan ekonomi domestik, tingkat hasil investasi (suku bunga dan deviden), nilai tukar dan indikator risiko dalam negeri. Oleh karena itu, perlu penelitian dengan pendekatan pull and push factors dalam rangka mengetahui faktor apa yang paling berpengaruh dalam rangka mendatangkan aliran modal asing di suatu negara.

\section{METODE}

Penelitian ini menggunakan metode kuantitatif dengan pendekatan ekonometrika dan menggunakan data sekunder dalam bentuk time series. Adapun sampel yang menjadi unit analisis adalah aliran modal asing, GDP domestik, GDP global, suku bunga domestik, suku bunga internasional, risiko politik negara, risiko global dan penanaman modal dalam negeri pada tahun 1998 - 2017.Metode analisis data menggunakan model persamaan Regressi linear berganda dengan model persamaan sebagai berikut:

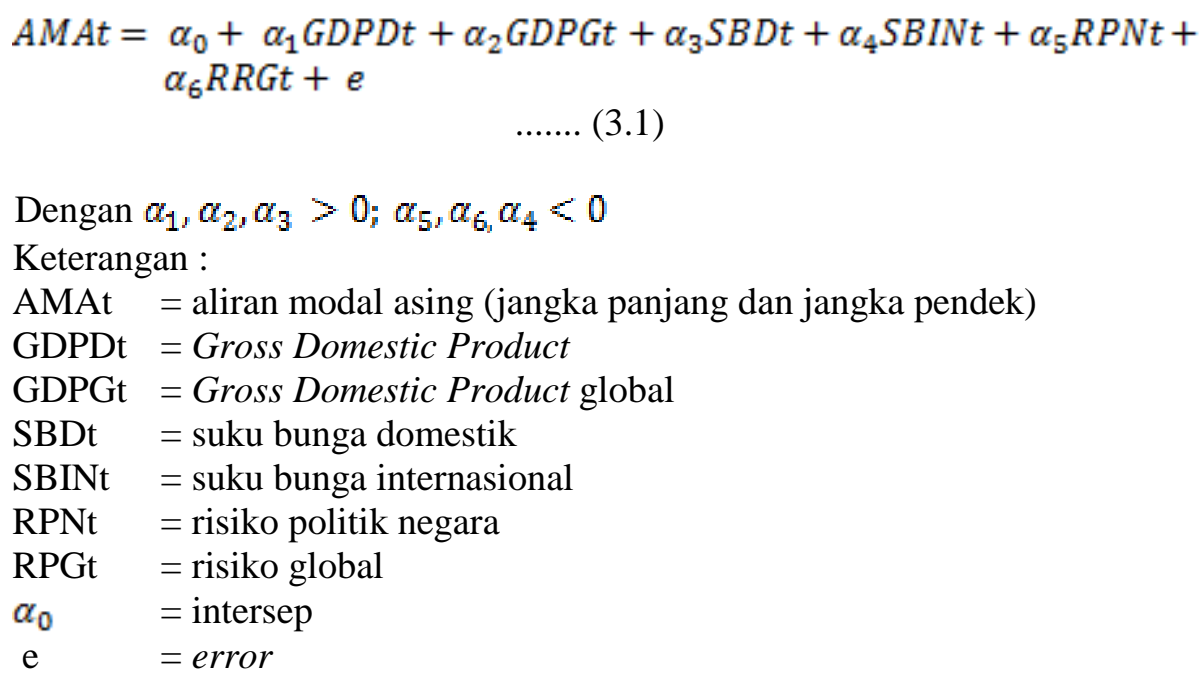




\section{Jurnal Administrare: Jurnal Pemikiran Ilmiah dan Pendidikan Administrasi Perkantoran Vol. 5, No. 2, Juli - Desember 2018, Hal 77-84}

\section{HASIL PENELITIAN DAN PEMBAHASAN}

\section{Deskripsi modal Asing ke Indonesia}

Secara umum aliran modal yang masuk di Indonesia dikelompokkan menjadi tiga yaitu foreign direct investment, portofolio investmen dan other investmen. Dari ketiga komponen aliran modal asing, foreign direct investment dan portofolio investmen yang dominan menopang pergerakan aliran modal asing di Indonesia. Berikut perkembangan aliran modal asing di Indonesia:

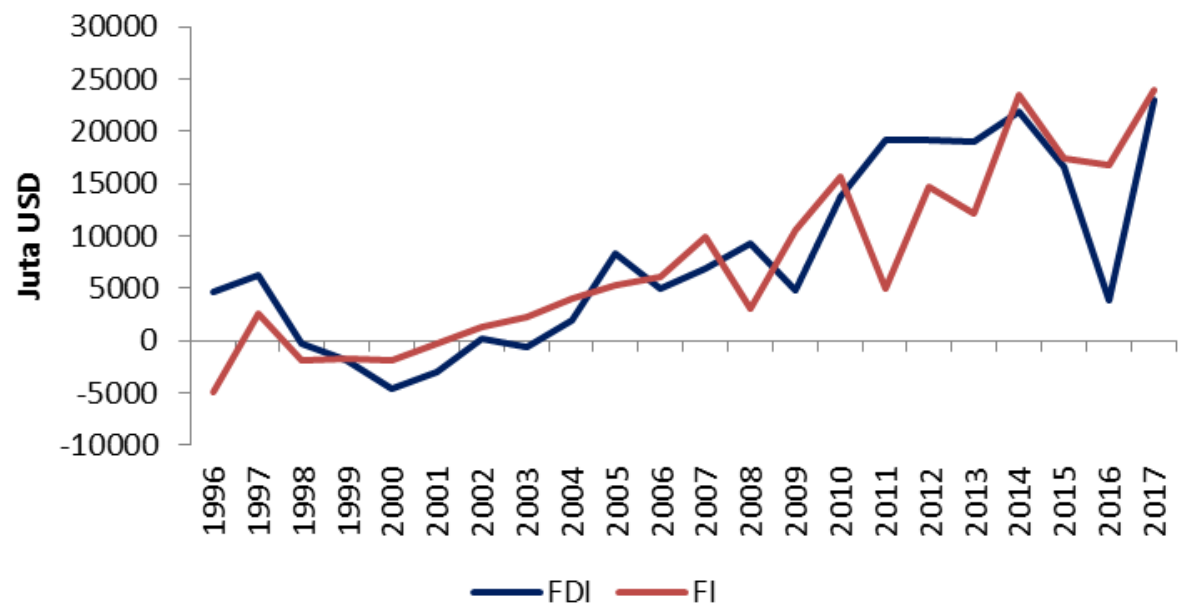

(Sumber: Bank Indonesia)

Gambar 2 Perkembangan Aliran Modal Asing

Selama periode penelitian dari tahun 1996 - 2017 pergerakan aliran modal asing baik foreign direct investmen dan portofolio investmen menunjukkan trend peningkatan, meski pada tahun-tahun tertentu mengalami fluktuasi. Meningkatnya aliran modal asing ke Indonesia menunjukkan bahwa kepercayaan luar negeri terhadap stabilitas ekonomi di Indonesia masih tinggi.

Aliran modal asing terendah terjadi pada periode krisis 1998 - 2001 yang berada diangka minus, ini tidak lepas dari krisis yang terjadi selama periode tersebut. Untuk kasus foreign direct investmen meskipun mengalami surplus pada tahun 2016, namun surplus tersebut mengalami penurunan signifikan. Penurunan surplus tersebut terutama dipengaruhi oleh arus keluar investasi langsung di sektor pertambangan. Portoflio investmen juga mengalami penurunan pada tahun 2016 dan indikasi penurunan sudah terlihat di tahun 2015. Kinerja tersebut disebabkan oleh ketidakpastian perekonomian global pada tahun 2016 pasca pemilihan Presiden Amerika Serikat dan ekspektasi kenaikan Fed Fund Rate yang menyebabkan keluarnya dana asing dari Indonesia.

Iklim investasi di Indonesia masih belum kondusif karena stabilitas sosial dan politik serta jaminan keamanan dan penegakan hukum masih rawan. Padahal dibadingkan dengan negara emerging market lainnya sebenarnya Indonesia memiliki keunggulan komparatif. Untuk 
Basri Bado, Arung Samudera, Muhammad Imam Ma'ruf; Analisis aliran modal asing ..... 81

aliran modal asing bidang usaha yang banyak diminati adalah perdagangan dan reparasi, jasa lainnya, industri logam dasar, mesin dan elektronika, angkutan, gudang dan telekomunikasi, industri tekstil serta pertambangan.

\section{Hasil Estimasi dan Pembahasan Aliran Modal Asing}

Tabel 1

Output Persamaan Portofolio Investment dan Pertumbuhan Ekonomi

\begin{tabular}{cccr}
\hline & Aliran Modal Asing Jangka Pendek & \\
\hline Variabel & Koefisien & T-Statistik & Prob \\
\hline BIRATE & -0.048942 & -0.642904 & 0.5347 \\
FFF & -0.262300 & -1.897849 & 0.0869 \\
GDPD & -0.959471 & -1.342523 & 0.2091 \\
GDPG & 0.191212 & 0.697550 & 0.5014 \\
GR & -0.070869 & -1.738015 & 0.1128 \\
RPD & 15.73867 & 2.741845 & 0.0208 \\
C & 7.220114 & 4.076117 & 0.0022 \\
\hline R-Squared & 0.786096 & & \\
\hline Adjusted R-Squared & 0.657753 & & \\
\hline F-Statistik & 6.771364 & & \\
\hline Prob F-Statistik & 0.004411 & \\
\hline DW & 3.037233 & &
\end{tabular}

Jumlah portofolio investment di Indonesia dipengaruhi oleh tingkat suku bunga domestik (BI rate), tingkat suku bunga internasional (Fed Fund Rate), jumlah GDP global, pertumbuhan ekonomi (GDP) Indonesia, tingkat risiko global dan tingkat risiko politik domestik. Berdasarkan hasil analisis diperoleh nilai koefisien determinasi $\left(R^{2}\right)$ sebesar 0,78 artinya persamaan tersebut dapat dijelaskan oleh keragaman variabel-variabel bebas sebesar 78 persen, sedangkan sisanya sebesar 22 persen dijelaskan oleh variabel lain di luar model (Tabel 4.1). Sementara itu, pertumbuhan ekonomi (GDP) di Indonesia dipengaruhi oleh jumlah portofolio investment di Indonesia dan penanaman modal dalam negeri (PMDN). Berdasarkan analisis diperoleh nilai koefisien determinasi $\left(R^{2}\right)$ sebesar 0,14 artinya persamaan tersebut dapat dijelaskan oleh keragaman variabel-variabel eksogen sebesar 14 persen, sedangkan sisanya sebesar 86 persen dijelaskan di luar model (Tabel 1).

Di dalam persamaan menunjukkan bahwa GDP tidak signifikan terhadap aliran modal asing jenis portofolio investment, namun sebaliknya pada persamaan kedua portofolio investment signifikan terhadap GDP. Hal ini menunjukkan bahwa para investor dalam rangka menggerakkan dananya ke Indonesia tidak begitu mempertimbangkan tingkat pertumbuhan ekonomi (GDP) Indonesia. Hal ini sejalan dengan penelitian Prasad et al (2006) yang menganalisis aliran modal asing dan pola pertumbuhan ekonomi di 59 negara berkembang selama periode 1970-2004, dalam penelitiannya menunjukkan beberapa negara yang memiliki pola pertumbuhan ekonomi yang rendah masih menerima aliran modal yang tinggi. Artinya, aliran modal asing tidak mengikuti pola pertumbuhan seperti diprediksi teori Neo-Klasik. Hal 


\section{Jurnal Administrare: Jurnal Pemikiran Ilmiah dan Pendidikan Administrasi Perkantoran Vol. 5, No. 2, Juli - Desember 2018, Hal 77-84}

berbeda terjadi pada tingkat pertumbuhan ekonomi (GDP) di Indonesia justru berpengaruh positif dan signifikan terhadap aliran modal asing jenis portofolio investment. Artinya, pertumbuhan ekonomi (GDP) di Indonesia sangat ditopang oleh aliran modal asing jenis portofolio investment.

Nilai koefisien Fed Fund Rate (FFF) sebesar -0,26. Hal ini menunjukkan bahwa setiap peningkatan Fed Fund Rate sebesar 1 persen akan menyebabkan penurunan jumlah portofolio investment sebesar 0,26 persen. Artinya, Fed Fund Rate berpengaruh negatif terhadap portofolio investment, dan dinyatakan sesuai dengan kerangka teori bahwa setiap peningkatan suku bunga luar negeri yang diproksikan dengan Fed Fund Rate dapat mengakibatkan penurunan jumlah aliran modal asing jenis portofolio investment di Indonesia. Hasil ini juga diperkuat oleh hasil penelitian dari beberapa negara diantaranya Nuryakin, Yuan, \& Arsana (2016) yang meneliti faktor yang mempengaruhi aliran modal asing di Indonesia dan Liyanage (2016) di Sri Langka.

Nilai koefisien risiko global sebesar -0,07. Hal ini menunjukkan bahwa setiap peningkatan GDP global sebesar 1 persen akan menyebabkan penurunan jumlah portofolio investment sebesar 0,07 persen. Artinya, risiko global berpengaruh negatif terhadap portofolio investment, dan dinyatakan sesuai dengan kerangka teori di mana setiap peningkatan risiko global yang diproksikan dengan VIX indeks dapat mengakibatkan penurunan jumlah aliran modal asing jenis portofolio investment di Indonesia. Semakin tinggi tingkat risiko global, menunjukkan kinerja pasar yang memburuk, sebaliknya semakin rendah tingkat risiko global maka menunjukkan kinerja pasar yang semakin baik untuk investasi. Hal ini menjadi pertimbangan para investor dalam melakukan investasi dibeberapa negara. Hasil ini sejalan dengan temuan Perry (2016).

Nilai koefisien risiko politik domestik sebesar 27,48. Hal ini menunjukkan bahwa setiap peningkatan risiko politik domestik sebesar 1 persen akan menyebabkan peningkatan jumlah foreign direct investment sebesar 27,48 persen. Artinya, risiko politik domestik berpengaruh positif terhadap foreign direct investment, dan dinyatakan sesuai dengan kerangka teori di mana setiap peningkatan risiko politik domestik dapat mengakibatkan peningkatan jumlah aliran modal asing jenis foreign direct investment di Indonesia. Semakin tinggi tingkat risiko politik domestik, menunjukkan iklim investasi yang semakin stabil, sebaliknya semakin rendah tingkat risiko politik domestik maka menunjukkan iklim investasi yang semakin memburuk. Risiko politik domestik menjadi pertimbangan yang utama para investor karena risiko politik domestik menggambarkan suatu negara layak investasi. Risiko politik domestik terdiri dari beberapa komponen yaitu akuntabilitas demokrasi, stabilitas politik, pemerintahan yang efektif, kualitas regulasi, kepastian hukum dan kontrol atas korupsi. Hasil yang diperoleh diperkuat dengan beberapa temuan yang menyatakan bahwa kondisi politik dan bisnis yang menguntungkan di negara tuan rumah maka akan signifikan mempengaruhi aliran modal asing dalam bentuk foreign direct investment (Griebeler \& Wagner, 2017; Kuzmina, Volchkova, \& Zueva, 2014; Mukherjee \& Sinha, 2016; Pekarskiene \& Susniene, 2015; Wang, 2017). Lebih lanjut bahwa ketidakstabilan politik akan mengurangi kepercayaan investor untuk berinvestasi (Liyanage, 2016). 


\section{SIMPULAN}

Berdasarkan pendekatan pull factors dan push factors ternyata faktor yang dominan mempengaruhi aliran modal asing adalah pull factors baik jenis portofolio investment dan foreign direct investment. Variabel yang paling dominan mempengaruhi aliran modal asing di Indonesia yaitu variabel risiko politik domestik. Risiko politik domestik erat kaitannya dengan iklim investasi. Disisi lain pengaruh aliran modal asing signifikan dan positif dalam menjelaskan pertumbuhan ekonomi di Indonesia. Oleh karena itu, untuk menggerakkan aliran modal asing masuk ke dalam negeri dalam rangka meningkatkan pertumbuhan ekonomi maka harus dilakukan perbaikan terhadap iklim investasi di Indonesia.

\section{DAFTAR PUSTAKA}

Ahmed, S., \& Zlate, A. (2014). Capital flows to emerging market economies: A brave new world? Journal of International Money and Finance, 48, 221-248. https://doi.org/https://doi.org/10.1016/j.jimonfin.2014.05.015

Davis, J. S., \& Presno, I. (2017). Capital controls and monetary policy autonomy in a small open economy. Journal of Monetary Economics, 85, 114-130. https://doi.org/https://doi.org/10.1016/j.jmoneco.2016.11.008

Dossani, R., \& Kenney, M. (2002). Creating an Environment for Venture Capital in India. World Development, 30(2), 227-253. https://doi.org/https://doi.org/10.1016/S0305750X(01)00110-3

Griebeler, M. de C., \& Wagner, E. M. (2017). A signaling model of foreign direct investment attraction. EconomiA, 18(3), 344-358.

https://doi.org/https://doi.org/10.1016/j.econ.2017.04.001

Guzman, M., Ocampo, J. A., \& Stiglitz, J. E. (2018). Real exchange rate policies for economic development. World Development, 110, 51-62.

https://doi.org/https://doi.org/10.1016/j.worlddev.2018.05.017

Kersten, R., Harms, J., Liket, K., \& Maas, K. (2017). Small Firms, large Impact? A systematic review of the SME Finance Literature. World Development, 97, 330-348.

https://doi.org/https://doi.org/10.1016/j.worlddev.2017.04.012

Koepke, R. (2015). What drives capital flows to emerging markets? A survey of the empirical literature.

Kuzmina, O., Volchkova, N., \& Zueva, T. (2014). Foreign direct investment and governance quality in Russia. Journal of Comparative Economics, 42(4), 874-891.

https://doi.org/https://doi.org/10.1016/j.jce.2014.08.001 


\section{Jurnal Administrare: Jurnal Pemikiran Ilmiah dan Pendidikan Administrasi Perkantoran Vol. 5, No. 2, Juli - Desember 2018, Hal 77-84}

Liyanage, E. (2016). Determinants of capital inflows: Evidence from Sri Lanka. Staff Studies, 44(1-2).

Marcelin, I., \& Mathur, I. (2016). Financial sector development and dollarization in emerging economies. International Review of Financial Analysis, 46, 20-32. https://doi.org/https://doi.org/10.1016/j.irfa.2016.04.010

Montiel, P., \& Reinhart, C. M. (1999). Do capital controls and macroeconomic policies influence the volume and composition of capital flows? Evidence from the 1990s. Journal of International Money and Finance, 18(4), 619-635. https://doi.org/https://doi.org/10.1016/S0261-5606(99)00021-2

Mukherjee, A., \& Sinha, U. B. (2016). Competition, foreign direct investment and welfare. Economics Letters, 139, 43-45. https://doi.org/https://doi.org/10.1016/j.econlet.2015.12.013

Nuryakin, C., Yuan, E. Z. W., \& Arsana, I. G. P. (2016). Portfolio Flows into Indonesia: Push or Pull? Economics and Finance in Indonesia, 62(2), 121-126.

Pekarskiene, I., \& Susniene, R. (2015). Features of Foreign Direct Investment in the Context of Globalization. Procedia - Social and Behavioral Sciences, 213, 204-210. https://doi.org/https://doi.org/10.1016/j.sbspro.2015.11.427

Situmorang, J. W. (2011). Menguak iklim investasi Indonesia pascakrisis. Esensi.

Vo, X. V. (2018). Determinants of capital flows to emerging economies - Evidence from Vietnam. Finance Research Letters, 27, 23-27. https://doi.org/https://doi.org/10.1016/j.frl.2018.02.031

Wang, L.-H. (2017). Accounting quality and information asymmetry of foreign direct investment firms. Research in International Business and Finance, 42, 950-958. https://doi.org/https://doi.org/10.1016/j.ribaf.2017.07.029

Zaman, Q. U., Hassan, M. K., Akhter, W., \& Meraj, M. A. (2018). From interest tax shield to dividend tax shield: A corporate financing policy for equitable and sustainable wealth creation. Pacific-Basin Finance Journal, 52, 144-162. https://doi.org/https://doi.org/10.1016/j.pacfin.2017.01.003 